\title{
PENGEMBANGAN ALAT PRAKTIKUM HUKUM OHM BERBASIS GRAFIK MENGGUNAKAN MIKROKONTROLER PADA MAHASISWA CALON GURU FISIKA
}

\author{
Aslam, Syamsu, Darsikin dan Unggul Wahyono \\ Aslamnapi@gmail.com \\ Program Studi Pendidikan Fisika FKIP Universitas Tadulako \\ Jl. Soekarno Hatta Km. 9 Kampus Bumi Tadulako Tondo Palu - Sulawesi Tengah
}

\begin{abstract}
Abstrak: Tujuan penelitian ini adalah untuk menghasilkan alat praktikum hukum ohm berbasis grafik menggunakan mikrokontroler pada mahasiswa calon guru fisika. Proses penelitian ini merupakan penelitian pengembangan, yang mengacu pada model Sugiyono. Instrumen penelitian yang digunakan adalah angket dengan skala likert empat yang ditujukan kepada ahli media, asisten laboratorium dan mahasiswa Pendidikan Fisika Universitas Tadolako. Data kualitas produk yang diperoleh dianalisis dengan menggunakan analisis deskriptif. Kualitas produk berdasarkan hasil analisis penilaian ahli media diperoleh nilai 3,34 dengan interprestasi "Sangat Baik". Analisis penilaian asisten laboratorium diperoleh nilai 3,52 dengan interprestasi "Sangat Baik". Sedangkan hasil tanggapan mahasiswa pada uji coba terbatas diperoleh nilai 3,45 dengan interprestasi "Sangat Setuju". Hasil uji coba dan analisis angket menunjukkan bahwa alat praktikum hukum ohm yang dikembangkan layak untuk digunakan.
\end{abstract}

Kata Kunci: Alat Praktikum Hukom Ohm, Berbasis Grafik dan Mikrokontroler

\section{PENDAHULUAN}

Pembelajaran fisika merupakan suatu proses untuk mengembangkan kemampuan pemahaman konsep, prinsip dan hukum-hukum fisika sehingga dalam proses pembelajarannya harus dipertimbangkan strategi atau model pembelajaran yang efektif dan efisien yang akan digunakan. Dalam mempelajari gejala atau fenomena alam, fisika menggunakan proses yang terdiri atas; pengamatan, pengukuran, analisis, dan penarikan kesimpulan. Hal-hal tersebut dapat kita lakukan sebagai satu kesatuan dalam praktikum [1].

Praktikum dalam pembelajaran fisika merupakan suatu rangkaian kegiatan pembuktian dan pengembangan konsep fisika yang telah dipelajari secara abstrak melalui buku, internet dan pembelajaran di kelas. Hal ini perlu dilakukan dengan harapan selain memiliki pengetahuan yang bersifat abstrak, peserta didik juga memiliki pengalaman penerapan pengetahuan secara nyata berupa praktikum yang dilakukan di sekolah. Hal tersebut menjadikan peserta didik tidak hanya sebatas mengingat ilmu pengetahuan, namun lebih pada pemahaman terhadap ilmu pengetahuan tersebut. Sebab, belajar dengan menggunakan alat praktik memberi kesempatan kepada peserta didik untuk dapat melihat dan membuktikan teori yang telah dipelajari, melalui pengamatan dan percobaan secara langsung. Hal ini tentunya akan meningkatkan kreativitas, dan keterampilan. Dengan demikian akan lebih termotivasi dalam mengkaji suatu teori, dan secara tidak langsung rasa keingintahuan juga turut berkembang dan lebih besar dalam proses belajar.

Berdasarkan hal tersebut maka praktikum sangat penting pada proses pemebelajaran IPA khususnya fisika karena banyak sekali teori yang perlu dibuktikan melalui praktikum selain itu praktikum juga dapat memberikan pengetahuan lebih, bahkan sampai bisa menemukan seuatu yang sebelumnya belum pernah ada.

Fisika tidak terlepas dari gambar-gambar untuk mengilustrasikan kejadian sebenarnya yang terjadi di lapangan atau untuk melukiskan suatu proses yang tidak dapat dilihat langsung oleh mata. Gambaran ini dapat berupa gambar 3 dimensi, grafik, bagan atau yang lainnya. Bentuk gambar yang biasanya digunakan untuk mengilustrasikan suatu proses adalah grafik atau bagan [2].

Kemampuan mengilustrasikan grafik merupakan persyaratan yang dituntut dalam pelajaran IPA, karena pada pelajaran fisika grafik merupakan satu alat bantu yang digunakan dalam sains untuk menampilkan 
data dan untuk membantu menganalisis hubungan antara variabel-variabel [3].

Grafik dapat menjelaskan suatu konsep secara praktis dan efisien. Grafik memberikan kemudahan dalam memahami konsep - konsep fisika terlebih pada materi listrik khususnya pada hukum ohm sehingga dibutuhkan sebah alat ukur yang hasil pengukurannya berupa gambar grafik untuk membuktikan hal tersebut. Ada banyak sekali alat - alat praktikum yang tersedia di laboratorium namun alat praktikum yang berbasis grafik masih sangat kurang atau dengan kata lain alat - alat praktikum yang tersedia masih analog, sehigga dibutuhkan alat praktikum yang lebih inovatif yang data hasil pengukurannya bukan hanya berupa data tetapi dilengkapi dengan gambar grafik.

\section{METODE PENELITIAN}

Penelitian ini termasuk jenis penelitian dan pengembangan atau dikenal Research and Developement (R\&D) yaitu model penelitian yang digunakan untuk menghasilkan produk tertentu, dan menguji keefektifan produk tersebut [4].

Penelitian pengembangan alat praktikum hukum ohm berbasisi grafik, diadaptasi dari langkah-langkah model penelitian pengembangan oleh Sugiyono. Langkahlangkah penelitian secara umum adalah seperti yang ditunjukan pada gambar 1 .

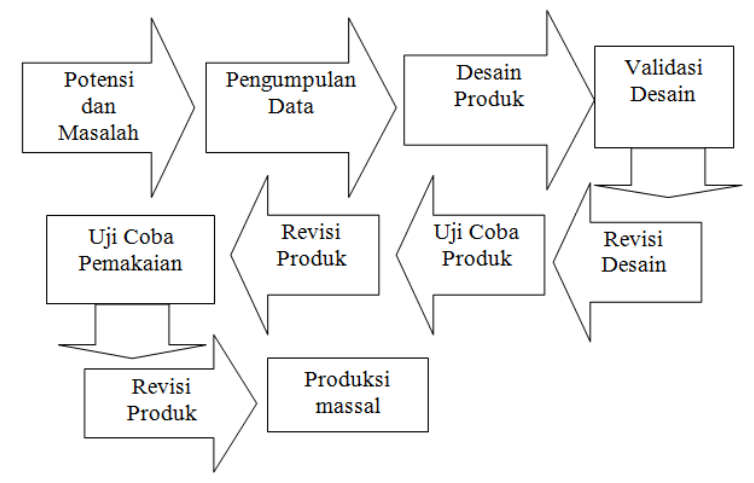

Gambar 1. Langkah-langkah metode Research and Development

Langkah-langkah dalam penelitian ini penelitian hanya sampai pada tahap revisi produk. Dari gambar 1 maka langkah-langkah yang dilaksanakan meliputi:
1. Potensi dan masalah

Penelitian dapat diangkat dari adanya potensi atau masalah. Potensi adalah segala sesuatu yang apabila didayagunakan akan memiliki nilai tambah. Sedangkan masalah adalah penyimpangan antara kenyataan dan harapan.

2. Pengumpulan data

Setelah potensi masalah disajikan secara faktual, selanjutnya akan dilakukan pengumpulan bahan-bahan yang diperlukan untuk membuat media. Bahan-bahan yang dibutuhkan seperti gambar-gambar sebagai pelengkap dan lain sebagainya.

3. Desain produk

Setelah dikumpulkan berbagai macam data yang dibutuhkan, maka selanjutnya proses pembuatan alat. Proses ini adalah proses dimana gambar rangkaian dari alat yang akan dibuat. Pada penelitian ini akan dibuat produk yang akan dikembangkan.

4. Validasi desain

Validasi ini berguna untuk mengetahui apakah produk yang dibuat layak diujikan atau tidak. Validasi dilakukan melalui diskusi dengan ahli. Ahli disini adalah ahli media yang berkompeten dibidangnya.

5. Revisi desain

Setelah melewati proses validasi, maka akan diketahui kelemahan-kelemahan produk yang dibuat. Kelemahan tersebut kemudian dikurangi dengan memperbaiki bagianbagian yang dirasa masih kurang.

6. Uji coba produk

Langkah selanjutnya adalah dengan menguji coba produk, Uji coba dilakukan kepada lima orang asisten laboratrium Pendidikan Fisika dan tiga belas mahasiswaPendidikan Fisika

7. Revisi produk Langkah revisi merupakan langkah terakhir dari penelitian ini, dan setelah revisi maka produk sudah bisa digunakan. Selanjutnyapenulisan laporan penelitian. Model pengembangan dalam penelitian ini menggunakan model prosedural yaitu model yang bersifat deskriptif, menunjukkan langkah-langkah yang harus diikuti untuk mnghasilkan produk berupa alat praktikum.

Subjek penelitian ini adalah seluruh mahasiswapendidikan fisika angkatan 2013. Karena penelitian ini adalah penelitian dan pengembangan dengan uji terbatas, maka hanya sebagian saja mahasiswa yang diambil sebagai subjek penelitian untuk menilai kelayakan alat praktikum. 
Instrumen yang digunakan pada penelitian ini adalah berupa angket yang diberikan kepada ahli media, asisten dan mahasiswa sebagai respondennya.

Data yang diperoleh melalui instrumen penilaian pada saat uji coba dianalisis dengan menggunakan statistik deskriptif kualitatif yang memaparkan hasil pengembangan produk alat praktikum berupa alat ukur hukum ohm berbasis grafik. Analisis ini dimaksud untuk menggambarkan karakteristik data pada masing-masing variabel. Dengan cara ini diharapkan dapat mempermudah memahami data untuk proses selanjutnya. Hasil analisis data digunakan sebagai dasar untuk merevisi produk media yang dikembangkan.

Teknik analisis yang digunakan untuk menganalisis data hasil validasi adalah perhitungan nilai rata-rata. Penentuan teknik analisis nilai rata-rata ini berdasarkan pendapat dari Arikunto[5] yang menyatakan bahwa untuk mengetahui peringkat nilai akhir pada setiap butir angket penelitian, jumlah nilai yang diperoleh dibagi dengan banyaknya responden yang menjawab angket penilaian tersebut [5]. Sehingga diperoleh rumus untuk menghitung nilai rata-rata adalah:

$$
\bar{X}=\frac{\sum x}{n}
$$

Keterangan :

$\bar{X}$ : nilai rata-rata dalam tiap butir pertanyaan

$\sum x$ : jumlah nilai dari seluruh penilaian dalam tiap butir pertanyaan

$n$ : jumlah butir pernyataan

Cara Mengubah skor rata-rata yang diperoleh melalui angket ke dalam bentuk kualitatif berdasarkan tabel 1 [6].

TABEL 1 KATEGORI SKALA LIKERT

$\begin{array}{cc}\text { Skor } & \text { Interprestasi } \\ 3,25<\bar{X} \leqslant 4,00 & \text { Sangat baik (SB) } \\ 2,50<\bar{X} \leqslant 3,25 & \text { Baik (B) } \\ 1,75<\bar{X} \leqslant 2,50 & \text { Kurang (K) } \\ 1,00 \leqslant \bar{X} \leqslant 1,75 & \text { Sangat Kurang (SK) }\end{array}$

Analisis data respon mahasiswa serupa dengan analisis kualitas penilaian produk. Ratarata skor dari angket respon selanjutnya diubah ke dalam bentuk kualitatif berdasarkan tabel 2 .
TABEL 2 KRITERIA KATEGORI RESPON MAHASISWA

\begin{tabular}{cc}
\hline Skor & Interprestasi \\
\hline $3,25<\bar{X} \leqslant 4,00$ & Sangat baik (SB) \\
$2,50<\bar{X} \leqslant 3,25$ & Baik (B) \\
$1,75<\bar{X} \leqslant 2,50$ & Kurang (K) \\
$1,00 \leqslant \bar{X} \leqslant 1,75$ & Sangat Kurang (SK)
\end{tabular}

Skor penilaian atau tingkat kelayakan baik setiap aspek maupun keseluruhan terhadap alat ukur hukum ohm menggunakan Tabel 2, Sebagai acuan penilaian data yang dihasilkan dari validitas ahli media, asisten laboratorium Pendidikan Fisika serta uji coba pada peserta didik agar mempermudah dalam pemberian suatu kriteria nilai bahwa alat praktikum hukum ohm berbasis grafik yang dikembangkan sudah layak atau belum untuk digunakan.

\section{HASIL DAN PEMBAHASAN}

\section{A. Hasil Penelitian \\ 1. Penilaian Kualitas Alat oleh Ahli}

Aspek yang diniliai oleh ahli meliputi desain program, desain alat, kualitas dan efektifitas alat, pengoprasian dan kinerja alat praktikum dan kesesuaian alat praktikum dengan konsep hukum ohm. Hasil penilaian oleh ahli disajikan dalam diagram seperti pada gambar 2 .

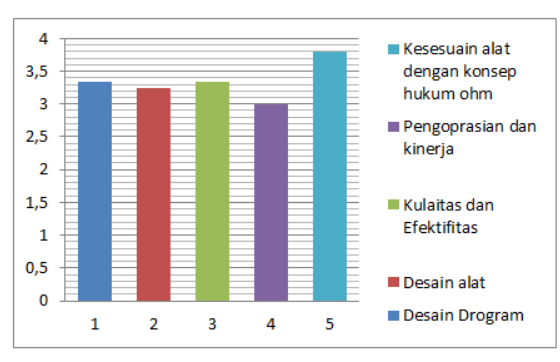

Gambar 2. diagram penilaian ahli

Adapun saran dan kritik oleh ahli adalah :

1) Prosedur kerja secara ringkas belum ditunjukan

2) Analisa data secara grafis belum nampak

3) Ralat secara digital belum nampak

4) Harus lebih inofatif

5) Ukuran huruf dan jenis huruf harus lebih compatible

\section{Penilaian Kualitas Alat oleh Asisten Laboratorium Pendidikan Fisika}

Aspek yang dinilai oleh asisten laboratorium Pendidikan Fisika Fakultas Keguruan dan Ilmu Pendidikan (FKIP) Universitas Tadulako 
(UNTAD) meliputi penampilan fisik alat praktikum, pengoperasian dan kinerja alat praktikum, kualitas dan efektifitas alat praktikum, hasil pengukuran alat, dan aspek teknis. Penilaian ini dilakukan oleh 5 orang asisten laboratorium Pendidikan Fisika. Hasil penilaian oleh asisten disajikan dalam diagram seperti pada gambar 3 .

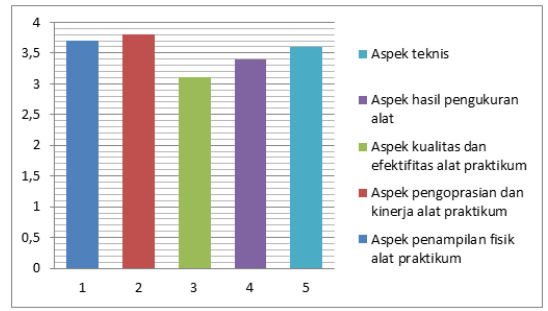

Gambar 3. diagram penialain oleh asisten laboratorium Pendidikan Fisika

Adapun saran dan keritik oleh asisten adalah:

1) Pada program isikan Gambar hukum ohm,

2) Pada box alat, penutup satu sisi saja yang dilepas,

3) Tampilan harus disertai dengan keterangan besaran yang diukur dan sebaiknya diwarnai,

4) Untuk alat dan hambatan gunakan satu papan rangkaian, dan

5) Tampilan softwere untuk ke menu pengukuran lebih diperjelas.

\section{Hasil Tanggapan pada Uji Terbatas}

Hasil tanggapan seluruh aspek kriteria alat praktikum oleh mahasiswapada uji terbatas meliputi lima aspek yaitu aspek penampilan fisik alat praktikum, aspek motivasi belajar hukum ohm dengan alat, aspek pengoprasian alat, aspek kualitas alat dan aspek hasil pengukuran. Penilaian ini dilakukan oleh 13 orang mahasiswa Pendidikan Fisika. Hasil penilaian oleh mahasiswadisajikan dalam diagram seperti pada gambar 4 .

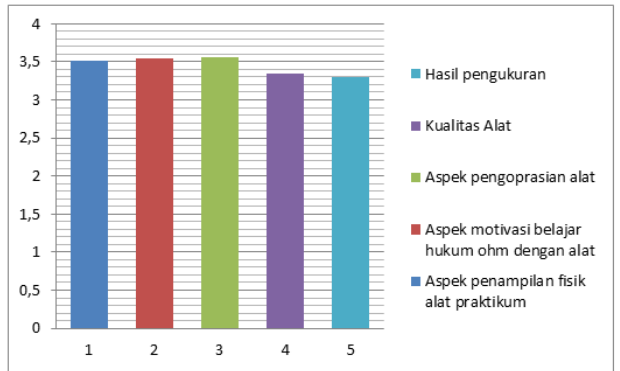

Gambar 4. diagram penialain oleh mahasiswaPendidikan Fisika
Adapun saran dan kritik secara umum dari hasil tanggapan pada uji terbatas untuk alat praktikum hukum ohm berbasis grafik menggunakan mikrokontroler adalah:

1) Tampilan grafiknya dibuat lebih menarik lagi, dan

2) Prosedur kerjanya buat lebih rinci lagi.

\section{B. Pembahasan}

Penelitian ini bertujuan untuk menghasilkan alat praktikum yang berbasis grafik. Dengan adanya pengembangan alat praktikum ini diharapkan dapat bermanfaat bagi mahasiswadalam memudahkan memahami materi hukum ohm, dapat menjadi alat alternatif saat melakukan praktikum hukum ohm serta dapat dijadikan tambahan referensi untuk penelitian selanjutnya tentang pengembangan alat praktikum Fisika pokok bahasan lain. Analisis data hasil pengembangan alat praktikum hukum ohm berbasis grafik menggunakan mikrokontroler didasarkan pada hasil validasi dan uji coba terbatas.

Alat praktikum yang dimaksud dalam penelitian ini adalah praktikum yang hasil pengukuranya selain data hasil pengukuran juga menghasilkan Gambar grafik hubungan antara $v$ dan i. Untuk menampilkan hasil pengukuran di gunakan laptop yang sudah ada softwere interfacenya untuk melihat data dan Gambar grafik hasil pengukuran. Alat praktikum yang dibuat oleh peneliti tidak perlu lagi menggunakan power supplay sebagai sumber tegangan karena alat ini menggunakan sumber tegangan pada port usb laptop. Selain itu, data hasil pengukuran dapat di copy paste karena data hasil pengukuran tersimpan secara otomatis.

Alat yang telah dirancang kemudian di validasi oleh ahli. Ahli yang dimaksud adalah ahli yang berkompeten dibidangnya. Ahli dalam penelitian ini adalah satu orang dosen Pendidikan Fisika FKIP UNTAD. Penilaian oleh ahli menggunakan instrumen penilaian untuk mendapatkan tanggapan. Tanggapan dari ahli dijadikan sebagai acuan dalam penyempurnaan produk. Dalam hal ini adalah melakukan revisi tahap awal terhadap alat. Melalui penilaian pada ahli media terdapat beberapa masukan yang menyatakan bahwa alat harusnya dilengkapi modul yang dimpilkan pada interface, ukuran huruf tidak sesuai dalam hal ini ukuran huruf terlalu besar dan tampilan 
analisa data secara grafis nampak. Sedangkan penilaian kelayakan alat yang dilakukan oleh 5 orang asisten laboratorim Pendidikan Fisika memberi masukan Tampilan harus disertai dengan keterangan besaran yang diukur, pada modul harusnya disertai Gambar rangkaian hukum ohm agar memberikan kemudahan dalam merangkai alat untuk melakukan pengukuran hukum ohm. Peneliti kemudian melakuakan perbaikan sesuai dengan komentar ahli dan asisten. Hasil perbaikan peneliti terhadap komentar ahli meliputi membuat modul yang berisikan tujuan percobaan, teori singkat dan prosedur kerja. Perbaikan selanjutnya yaitu pada ukuran font yang semula menggunakan 16 diubah menjadi 12 dan perbaikan pada desain sehingga tampilan analisa data secara grafis lebih nampak.

Setelah tahapan revisi selesai dilakukan, kemudian dilanjutkan dengan uji coba terbatas. Uji coba secara terbatas ini dilakukan dalam skala kecil yaitu kepada 13 orang mahasiswaPendidikan Fisika FKIP UNTAD. Penilaian pada uji coba terbatas dilakukan dengan mengisi skala tanggapan yang kemudian diberi masukan dan dijadikan sebagai bahan untuk revisi kedua. Hasil tanggapan pada uji coba terbatas menunjukkan mahasiswa tertarik dan antusias ketika kegiatan uji coba terbatas berlangsung. Terlebih karena alat praktikum tersebut sangat mudah dioperasikan oleh mahasiswa didik. Hasil tanggapan mahasiswapada alat praktikum secara umum adalah membuat tampilan grafik yang lebih menarik lagi. Melalui beberapa tanggapan dari mahasiswa didik, diadakan revisi kedua dari alat praktikum terhadap hal-hal yang dianggap penting. Sedangkan beberapa tanggapan tidak dilakukan revisi yang dianggap tidak perlu.

Berdasarkan hasil penilaian ahli yang dilakukan oleh dosen Fisika FKIP UNTAD pada tanggal 26 november 2015, aspek yang dinilai dari alat praktikum hukum ohm tersebut meliputi aspek desain program, aspek desain alat, aspek kualitas dan efektifitas alat, aspek pengoprasian dan kinerja alat praktikum dan aspek kesesuaian alat praktikum dengan konsep hukum ohm. Hasil penilaian yang diperoleh kemudian dianalisis untuk mendapatkan hasil akhir berupa kualitas produk. Hasil penilaian masing - masing aspek adalah aspek desain program katogori sangat baik (SB) dengan nilai rata-rata 3,33, aspek desain alat kategori sangat baik (SB) dengan nilai rata-rata 3,25 , aspek kualitas dan efektifitas kategori sangat baik (SB) dengan nilai rata -rata 3,33, aspek pengoprasian dan kinerja kategori baik (B) dengan nilai rata rata 3,00, dan aspek Kesesuain alat dengan konsep hukum ohm kategori sangat baik (SB) dengan nilai rata - rata 3,80 .

Hasil penilaian seluruh aspek alat praktikum oleh lima orang asisten laboratorium Pendidikan Fisika FKIP unversitas Tadulako pada tanggal 30 november 2015, aspek yang dinilai adalah penampilan fisik alat praktikum, pengoperasian dan kinerja alat praktikum, kualitas dan efektifitas alat praktikum, hasil pengukuran alat, dan aspek teknis. Hasil penilian terhadap aspek penampilan fisik alat praktikum kategori sangat baik (SB) dengan nilai rata - rata 3,70, aspek pengoprasian dan kinerja alat praktikum kategori sangat baik (SB) dengan nilai rata rata 3,80, aspek kualitas dan efektifitas alat praktikum kategori baik (B) dengan nilai rata rata 3,10 , aspek hasil pengukuran alat kategori sangat baik (SB) dengan nilai rata - rata 3,40, dan aspek teknis kategori sangat baik (SB) dengan nilai rata - rata 3,60.

Hasil penilaian terhadap seluruh aspek alat praktikum oleh tiga belas orang mahasiswa Pendidikan Fisika FKIP Universitas Tadulako pada tanggal 2 desember 2015, penilain aspek alat praktikum meliputi aspek penampilan fisik alat praktikum, aspek motivasi belajar hukum ohm dengan alat, aspek pengoprasian alat, aspek kualitas alat dan aspek hasil pengukuran. Dari data hasil analisis angket terlihat bahwa angket pernyataan positif rata - rata mahasiswa memilih sangat setuju sedangkan angket pernyataan negatif rata - rata mahasiswa memilih kurang setuju, atau dengan kata lain mahaipeserta didik Pendidikan Fisika merespon baik dengan adanya alat praktikum hukum ohm berbasis grafik yang dirancang oleh peneliti.

Keunggulan alat praktikum hukum ohm berbasis grafik adalah mahasiswa dapat melihat langsung grafik hubungan antara tegangan dan arus, sehingga grafik hubungan antara tegangan dan arus tidak perlu lagi di gambar secara manual untuk membuktikan kelineran grafik tersebut. Alat praktikum ini dapat digunakan sebagai pengganti alat praktikum hukum ohm yang digunakan di laboratorium pada saat ini karena alat praktikum yang dibuat oleh peneliti tidak memerlukan waktu lama dalam pengambilan data selian itu data yang diperoleh sudah sangat lengkap sehingga 
praktikum tidak lagi terkesan sulit karena untuk membuktikan teori harus melalui praktikum. Alat praktikum yang dibuat oleh peneliti juga memliki bebrapa kelemahan yaitu tegangan maksimal yang dapat digunanakan adalah lima

\section{KESIMPULAN}

Berdasarkan analisis data dan pembahasan, maka penelitian ini dapat disimpulkan:

1) Telah dibuat alat praktikum hukum ohm berbasis grafik menggunakan mikrokontrler. Langkah yang dilakukan yaitu dimulai dengan pembuatan gambar rangkaian pada proteus 8.1, gambar lay out, merangkai alat

\section{DAFTAR PUSTAKA}

[1] Waris, Abdul (2015). Pengembangan Alat Praktikum SMP Daerah Terpencil. Skripsi Pada Jurusan Pendidikan Fisika FPMIPA, Universitas Tadulako Palu: Tidak Diterbitkan.

[2] Tadeko, Nurgan (2013). Analisis Pemahaman Soal Grafik Mahasiswa Pendidikan MIPA Menggunakan Pemodelan Rasch. Skripsi pada Jurusan Pendidikan Fisika FPMIPA, Universitas Tadulako Palu: tidak diterbitkan.

[3] Sulastri, Endang (2013). Analisis Kemampuan Menginterpretasikan Grafik Termodinamika Peserta didik SMA. Skripsi pada Jurusan Pendidikan Fisika FPMIPA, Universitas Tadulako Palu: tidak diterbitkan.

[4] Sugiyono. (2009). Metode Penelitian Kuantitatif, Kualitatif dan R\&D, Bandung: Alfabeta

[5] Arikunto, S. (2006). Prosedur Penelitian: Suatu Pendekatan Praktik. Jakarta: Rineka Cipta

[6] Widoyoko. (2012). Teknik Penyusunan Instrumens Penelitian. Yogyakarta: Pustaka Pelajaran volt dan arus yang dapat di terbaca hanya sampai pada satuan mili Ampere atau dengan kata lain untuk nilai mikro Ampere belum dapat diukur.

pada papan $\mathrm{PCB}$, dan pembuatan interface pada delphi 10.

2) Hasil penilaian yang diberikan oleh ahli, 5 orang asisten laboratorium Pendidikan Fisika beserta 13 orang mahasiswaPendidikan Fisika terhadap kelayakan produk, menunjukkan bahwa alat praktikum tersebut memenuhi kriteria sangat baik dan layak digunakan untuk praktikum hukum ohm. 